\title{
Celso Furtado. Anos de Formação 1938-1948: ojornalismo,o serviço público, a guerra, o doutorado
}

\author{
Title: Anos de Formação: 1938-1948: o jornalismo, o serviço público, a guerra, o doutorado \\ Author: Furtado, Celso \\ Edition: Organização de Rosa Freire d'Aguiar. Rio de Janeiro, Contraponto/Centro Internacio- \\ nal Celso Furtado, Arquivos Celso Furtado 6, 2014, 404 pp.
}

ISBN. 9788578661038

Pedro Cezar DUTRA FONSECA

Universidade Federal do Rio Grande do Sul

\begin{abstract}
A obra reúne escritos (artigos, cartas, entrevistas e anotações) de Celso Furtado (1920-2004) entre 1938 e 1948. Trata-se de livro precioso para os estudiosos do pensamento do autor, o mais conhecido economista brasileiro e o de trabalhos de maior envergadura associados à heterodoxia. Em primeiro lugar, porque o livro condensa varios trabalhos inéditos integrantes do arquivo pessoal do autor, ora catalogados e organizados por sua viúva, a jornalista e tradutora Rosa Freire d'Aguiar. Em segundo, por trazer a público escritos da época em que Furtado ainda não era autor consagrado, de modo a permitir que se acompanhe a fase inicial de sua trajetória intelectual, a gênese de sua formação e de muitas ideias que mais tarde defenderá. Os trabalhos mais conhecidos e reconhecidos de Furtado são os que desenvolveu a partir de sua presença na CEPAL, na década de 1950, quando se tornou o principal líder intelectual dessa instituição, juntamente com Raúl Prebisch. Havia uma curiosidade acerca de sua obra pregressa e, portanto, é indiscutível que tal lacuna ora é preenchida. Pode-se, ainda, acrescentar um terceiro motivo, que é evidenciar a atualidade de seu pensamento e, sobretudo, de suas preocupações intelectuais.
\end{abstract}

Deve-se mencionar, inicialmente, que a obra é o sexto volume da coleção "Arquivos Celso Furtado", a qual vem sendo publicada pelo Centro Internacional Celso Furtado, ${ }^{1}$ emparceria com a editora Contraponto. A referida coleção tem como principal propósito o resgate e publicação de escritos seus ainda inéditos ou pouco divulgados. No caso em pauta, o libro estende-se desde quando Furtado termina, aos 18 anos, os estudos secundários, até a conclusão, aos 28 anos, da tese de doutorado de economia em Paris. A abertura do libro coubea o trabalho de aula "Liberalismo Econômico", escrito em contexto turbulento da ditadura do Estado Novo, com ascensão do integralismo, movimento brasileiro de inspiração fascista, e da Guerra Civil Espanhola. Nele, Furtado já antecipa sua posição de crítico ao liberalismo econômico, evidenciando certo viés positivista, com forte teor organicista e evolucionista ("a base da nossa concepção da história é a evolução"), o qual, mais tarde, em A Fantasia Organizada (1985) reconhecerá ser influência de um tio. Também adianta seu distanciamento tanto do fascismo como comunismo soviético, ao corajosamente criticá-los em um mundo polarizado, bem como dá mostras de seuspendores literários, presentes de forma mais nítida nas seções seguintes do livro, especialmente em seus artigos de jornalismo e relatos sobre a Guerra. Constam da primeira dezesseis artigos para revistas e jornais escritos no Rio de Janeiro entre 1941 e 1946, sobre temas gerais, mas sempre a transparecer nítidamente seu ponto de vista. Já o segundo abrange relatos da guerra: em agosto de 1942 o Brasil declarou guerra ao Eixo. Furtado, com 22 anos, foi convocado, fez curso de oficial e integrou a Força Expedicionária Brasileira, tendo embarcado para a Europa em 1944. Embora devastada, esta lhe causou uma impressão que não mais apagaria de sua vida: a cultura, o resgate da história, a sociedade mais politizada e mais equilibrada, muito dife-

\footnotetext{
${ }^{1}$ Já publicados: 1. Ensaios sobre a Venezuela: subdesenvolvimento com abundância de divisas; 2. Economia do desenvolvimento: curso ministrado na PUC-SP em 1975; 3. O Nordeste e saga da Sudene, 1958-1964; 4. O Plano Trienal e o Ministério do Planejamento; e 5. Ensaios sobre Cultura e o Ministério da Cultura.
} 
rente do Nordeste brasileiro. Possivelmente sua experiência de vida deste período foi fundamental para demarcar sua teorização sobre a antinomia entre desenvolvimento e subdesenvolvimento. Mais tarde dirá: "Pela primeira vez nós, brasileiros, e homens do povo, entramos em contato direto com um grupo social que vivía uma cultura e florescia à sombra de todo um arcabouço de arte e tradição" (pág. 263). As correspondências e relatos dessa época são, sem dúvida, um presente aos estudiosos do pensamento de Furtado.

Nos anos em que morou no Rio de Janeiro, entre 1941 e 1946, Furtado escreveu varios pequenos textos sobre economia e administração pública, os únicos do livro de caráter mais técnico. Como era formado em Direito (inexistiam no Brasil na época cursos de Economia), os trabalhos ajudam a mostrar seu interesse pela área, e principalmente a crença no planejamento e na organização administrativa, que também aparecem em quatro artigos mais de opinião política. Destes, o mais surpreendente é o dedicado à análise da Carta Constitucional de novembro de 1937, outorgada pelo Estado Novo varguista, pois defende não haver mudança substantiva entre esta e a Constituição anterior, de 1891, nem mesmo no que tange ao federalismo (há certo consenso de que a referida Carta era extremamente centralizadora do poder em nível federal, ao contrário da anterior, que dava mais autonomía aos estados).

A parte final da obra, "Os Ares do Mundo Europeu, 1947-1948", traz escritos de Furtado que também se confundem com relatos de viagem-ricos por evidenciarem seus olhos atentos para a economia, a política e a arte da Europa do pós-guerra. Viajou para diversos países e conviveu com pessoas da França, Itália, Tchecoslováquia, Alemanha, Hungria e Rússia, dentre outros, e também com latino-americanos, como argentinos e mexicanos. Nesses artigos, suas impressões pessoais mesclam-se com opiniões de temas em voga, opina sobre artigos de jornais, livros e eventos culturais, além de relatar aspectos de discussões com amigos e colegas. $\mathrm{O}$ artigo "O fascismo como Ideologia", neste aspecto, deve ser destacado. A relação entre fascismo, psicologia de massas, nacionalismo e religião é explorada, bem como algumas diferenças que este assumira em diversos países antes da guerra. Fica patente sua rejeição às saídas totalitárias ou autoritárias, de direita ou de esquerda, convicção que o acompanhou ao longo da vida. Em uma época de descrença na democracia e na qual boa parte da esquerda latino-americana deixava-se fascinar pelo stalinismo, Furtado, mesmo crítico ao capitalismo liberal e adepto de reformas estruturais, alinhado politicamente à esquerda -fato que resultou na cassação de seus direitos políticos em 1964- nunca se afastou da crença na democracia.

Finalmente, devem-se destacar, dentre os artigos, o que trata da Bósnia e da Croácia-regiões pobres, de economia marcadamente agrária, a lembrar a América Latina. Este remete a outro, sobre a crise econômica inglesa de então: escrito em setembro de 1947, Furtado mostrajá ter consciência da tese da deterioração dos termos de intercâmbio (a qual implicava perda a os países agrários nas relações de troca com os países industriais), e que ficaria associada definitivamente a Prebisch após seu Manifesto de Havana, como Secretário-Executivo da CEPAL, em 1949, e também conhecida como tese Singer-Prebisch. Furtado atribui a crise inglesa ao fato de o país não conseguir mais manter as relações de troca favoráveis do comércio internacional que desfrutara no século XIX, diante da emergência de países de industrialização mais recente, inicialmente Alemanha e, depois, Estados Unidos. Reconhece, ainda, que a crise da economia inglesa e, principalmente, de sua industria poderia se aprofundar com a possibilidade de mais países se industrializarem, tendência que aponta ter começado após a I Guerra e tomado impulso após a Grande Depressão dos anos 30. Assim, de certo modo antecipaseu marco teórico de Formação Econômica do Brasil, de 1959, obra na qual demarca 1930 como o início no Brasil da industrialização por substituição de importações. Daí concluir: "Os chamados termos de comércio ("terms of trade") estavam sempre a favor daqueles países que se reservavam o quinhão industrial na divisão do trabalho entre as nações" (pág. 363). Encontrar nos primórdios do pensamento de Furtado tal tese, e principalmente em análise da economia inglesa -e não latinoamericana, como seria a hipótese mais plausível- é grande contribuição à história de seu pensamento, a qual, apenas ela, já valeria o libro inteiro. 